\title{
Potency of stored DNA derived from buccal mucosal epithelial cells for genotype analysis of interleukin $4-590 \mathrm{C} / \mathrm{T}$
}

\author{
Rezmelia Sari* ${ }^{\star}$, Alya Nur Fadhilah** ${ }^{*}$ Prayitno* \\ *Department of Periodontics, Faculty of Dentistry, Universitas Gadjah Mada, Yogyakarta, Indonesia \\ **Dentistry Study Program, Faculty of Dentistry, Universitas Gadjah Mada, Yogyakarta, Indonesia \\ *JI Denta No 1, Sekip Utara, Yogyakarta, Indonesia; $\bowtie$ correspondence: rezmelia_sari@mail.ugm.ac.id
}

Submitted: $23^{\text {rd }}$ July 2018; Revised: $30^{\text {th }}$ November 2018; Accepted: $14^{\text {th }}$ January 2019

\begin{abstract}
The genotype variation of the interleukin 4 (IL-4) gene on spot $-590 \mathrm{C} / \mathrm{T}$ is known to correlate with IL-4 protein expression in periodontitis, but the results found in the population are inconsistent. Sequencial genotype analysis of multiple genes often used stored DNA samples obtained from buccal mucosal epithelial cells. This study aims to determine the use of stored DNA samples obtained from buccal mucosal epithelial cells for genotype analysis specifically on $-590 \mathrm{C} / \mathrm{T}$ IL-4 genes. This is a descriptive analytical study. The samples were 58 DNA derived from the buccal mucosal epithelial cells taken by sterile cotton swab isolated with PrestoTM kit (GeneAid). The DNA has been stored for 2 years at $-20{ }^{\circ} \mathrm{C}$. The genotype analysis was conducted using PCR RFLP technique with BSmFI enzyme and the data were presented descriptively. The results show that $51.72 \%$ of the stored DNA is still in good condition and $37.9 \%$ can be used for genotype analysis. It was concluded that DNA derived from buccal mucosal epithelial cells stored at $-20{ }^{\circ} \mathrm{C}$ for 2 years can still be used for genotype analysis, but the quality of DNA is affected by storage time.
\end{abstract}

Keywords: buccal mucosal epithelium; genotype analysis; polymorphism -590 C/T IL-4 gene; stored DNA

\section{INTRODUCTION}

Periodontitis is an irreversible inflammation in periodontal tissue. The treatment of the disease is expensive and time consuming. Hence, it is necessary to identify its risk factors for prevention. Gene polymorphisms are known to be correlated with the risk of periodontitis, but the results obtained were inconsistent. This inconsistency led the researchers to analyze genotypes in each population because the results were influenced by ethnic and subject criteria. ${ }^{1}$

DNA from buccal epithelial cells was commonly used in genotype analysis. The process for obtaining this DNA is considered to be relatively easy, not invasive and appropriate for genetic studies. $^{2}$ Genotype analysis techniques can be conducted by polymerase chain reaction followed by restriction fragment length polymorphism (PCR RFLP). With this technique, certain DNA strains will be polymerized and digested with certain enzymes.
This process is relatively easy, inexpensive, and suitable for genotypical gradual analysis of multiple genes. In the gradual process of genotype analysis, DNA can be stored at $-20{ }^{\circ} \mathrm{C}$. Furthermore, it can taken out of the refrigerator and adjusted to room temperature. This process has several disadvantages such as DNA damage due to the temperature changes.

The IL-4 gene is one of the dominant antiinflammatory cytokines. Spot $-590 \mathrm{C} / \mathrm{T}$ in the promoter of IL-4 gene is known to affect the IL-4 protein and other cytokine responses to plaque bacteria. ${ }^{3}$ This study aims to determine the use of stored DNA for genotype analysis, especially at $-590 \mathrm{C} / \mathrm{T}$ genes IL-4.

\section{MATERIALS AND METHODS}

This is a descriptive analytic study involving 58 DNA derived from subjects who meet the inclusion criteria. The procedure was approved by ethic 
Majalah Kedokteran Gigi Indonesia. December 2019; 5(3): 139 - 142

ISSN 2460-0164 (print)

ISSN 2442-2576 (online)

commitee of Faculty of Dentistry Universitas Gadjah Mada (No. 001146/KKEP/FKG-UGM/ $\mathrm{EC} / 2017)$. All patients are clinically healthy, aged 30-50 years old, with a clinical attachment level of $\geq 3 \mathrm{~mm}$ in more than one tooth and pocket depth of $\geq 4 \mathrm{~mm}$. The DNA was derived from buccal mucosal epithelial cells by rubbing a sterile cotton swabs with a circular motion for 15-20 times. Then, DNA was isolated with Presto ${ }^{\mathrm{TM}}$ kit (GeneAid). The DNA was then stored at $-20{ }^{\circ} \mathrm{C}$ in elution buffer included in kit for 2 years (in period of multiple analysis of gene).

In PCR stage, we used 5'-ACTAGGCCTCA CCTGATACG-3 '(sense) and 5'-AGGTGTCGA TTTGCAGTGAC-3' (antisense) as a primer. The PCR cycle consisted of an initial denaturation at $95{ }^{\circ} \mathrm{C}$ for $5 \mathrm{~min}$, followed by 35 cycles of PCR denaturation at $95{ }^{\circ} \mathrm{C}$ for $30 \mathrm{~s}$, annealing at $56{ }^{\circ} \mathrm{C}$ for $45 \mathrm{~s}$, extension at $56^{\circ} \mathrm{C}$ for $45 \mathrm{~s}$, final extension at $72{ }^{\circ} \mathrm{C}$ for 1 minute, and the final synthesis stage was continued at $72{ }^{\circ} \mathrm{C}$ for 10 minutes. The PCR product was 646 bp., which was restricted with BSmFI enzyme (New England Biolabs, Hitchin, UK). Allele $\mathrm{C}$ was digested and formed to $601 \mathrm{bp}$ and $45 \mathrm{bp}$, while allele T was not digested (646 bp). ${ }^{3}$

\section{RESULTS}

From this study, we found that 30 of 58 DNA (57.7\%) were in good quality (Figure 1), while others can not be detected. The good quality DNA was used for $\mathrm{PCR}$ process and the PCR products were shown in Figure 2. Then, PCR products were digested with $B S m F I$ enzyme (Figure 3). The number of DNA that had been successfully restricted were 22 samples $(37.9 \%)$, and the genotype analysis showed that TT genotype was dominant (Table 1).

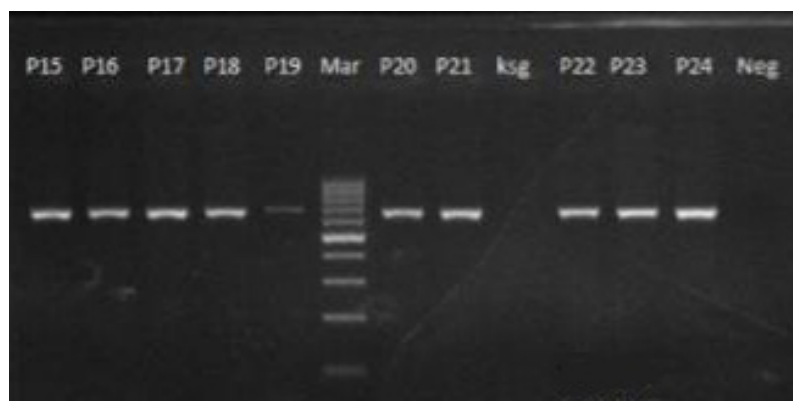

Figure 1. The quality of the stored DNA

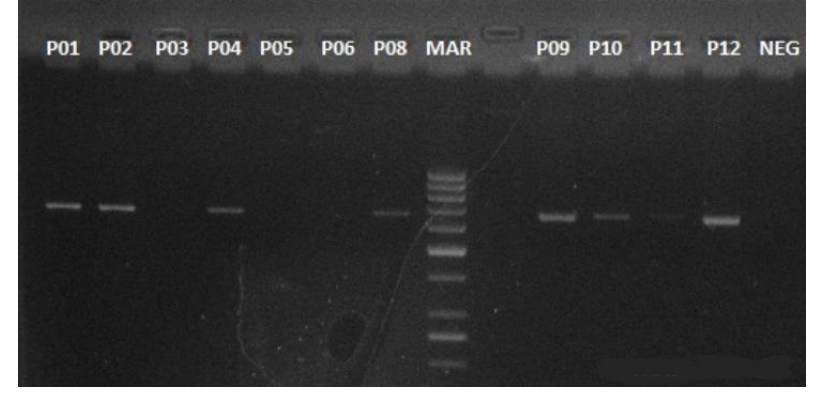

Figure 2. The PCR products

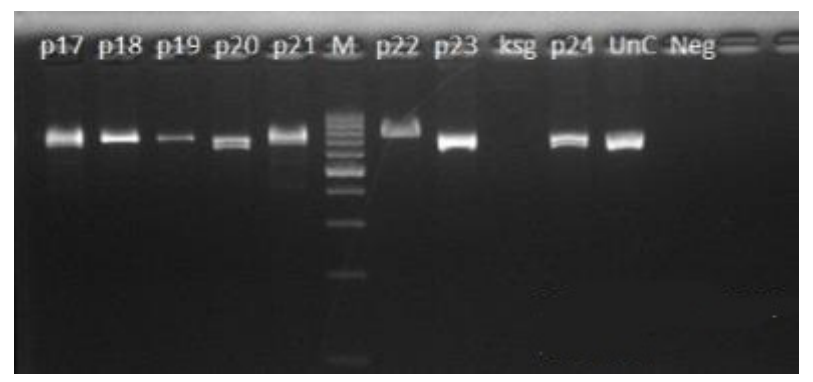

Figure 3. PCR products digested by BSmFI enzymes (New England Biolabs, Hitchin, UK)

Table 1. The genotype distribution of samples

\begin{tabular}{lcc}
\hline Genotype & $\mathrm{n}$ & Percentage (\%) \\
\hline CC (\%) & 0 & 0 \\
CT $(\%)$ & 2 & 9.09 \\
TT $(\%)$ & 20 & 90.9 \\
\hline
\end{tabular}

\section{DISCUSSION}

The relationship between periodontitis and individual genetic variation is complex. ${ }^{4}$ Genes are responsible for more than $50 \%$ of the risk of chronic periodontitis. Some studies have shown that such variation of genetic change the level of cytokines production and result in changes of immune responses and long lasting inflammations. Studies have reported the effect of single nucleotide polymorphisms in candidate genes in susceptibility to periodontitis. ${ }^{5}$

Genetic analysis using the PCR - RFLP methods utilizes DNA replication techniques with the help of primers that flanks the certain areas. To get the optimum process, optimization is carried out using several annealing temperatures. Determining this temperature is necessary to get an adequate DNA band. The temperature that is too high can fail the polymerization/amplification process because primary attachment will not occur, while the reverse 
can cause the primary attachment to the other side of the genome. The optimization results show that the optimal temperature used for polymerization with this primer is $56^{\circ} \mathrm{C}$. Then, the polymerization process was carried out using this temperature for the entire samples. This study succeeded in determining the genotype of 22 stored DNA samples. Mostly, the genotype is homozygous TT. These results cannot be compared with studies in other populations ${ }^{3}$ because not all samples can be digested.

In this study, we used DNA from buccal mucosal epithelial cells because it is non invasive, easy to obtain, and easy to extract. ${ }^{2}$ This is particularly beneficial if research on genetic variation is carried out in stages and involves several interrelated genes. In genotype analysis, the use of stored DNA is helpful to save time and costs. ${ }^{6}$ In addition to buccal mucous epithelial cells, DNA can also be obtained from various body organs, such as blood, hair, urine, sperm, bone, saliva, and teeth. ${ }^{7}$

This study proved that DNA that has been stored for 2 years can still be used as a sample for genotype analysis, especially for the IL-4 gene at spot $-590 \mathrm{C} / \mathrm{T}$. Before carrying out genetic analysis However, we have to check DNA quality to ensure that DNA is in good condition and not contaminated. The results indicated that most of DNA is still in good condition even though it has been stored for 2 years and has undergone a freeze and thaw process during previous gene examinations. Research using stored DNA has also been carried out to analyze genetic variation in IL-1 beta in menopausal women. ${ }^{8}$

Genotype analysis with PCR RFLP method was developed in 1987 and is a quite complex laboratory experiment. 9 Enzym restriction must be sufficient in quantity and quality to obtain optimum results. This study on the IL-4 gene, especially in promoter at spot 590 showed some difficulties in digesting the samples. This may be due to the nature of the gene that can form the hairpin, which can be attached to the other end after the clipping. It is possible to solve this problem using other methods of sequencing/scanning DNA sequences, but it requires a relatively more expensive cost.
The previous studies suggested that localized absence of IL-4 might lead to development of gingivitis to periodontitis. ${ }^{10}$ A significantly higher IL-4 level proves that there was a periodontitis lesion. It was further explained that the level of IL-4 in patient serum was higher in chronic periodontitis, but it could not show the degree of bone absorption and pocket formation.

In addition to IL-10, IL-4 plays an important role as an anti-inflammatory cytokine. This cytokine is produced by $\mathrm{T}$ helper 2 (Th-2) and have a function to modulate macrophage ${ }^{3}$ and monocyte apoptosis. $^{3}$ Furthermore, the previous study showed that polymorphism in promoter region on -590 of IL-4 can increase the IL-4 protein in periodontitis patients. It is also known to affect the expression level of other cytokines such as IL-6, TNF- $\alpha$, IL-1 $\beta$, IFN- $\gamma$ and IL-10. ${ }^{11}$ Polymorphism in IL-4 gene promoter region can also have an impact on the severity of periodontal disease by modulating cytokine response to bacterial plaque. ${ }^{3}$

\section{ACKNOWLEDGMENT}

This study was funded by Dana Masyarakat (research funding) of Faculty of Dentistry Universitas Gadjah Mada 2017.

\section{REFERENCES}

1. Lanni M, Bruzzesi G, Pugliese D, Porcellini E, Carbone I, Schiavone A, Licastro F. Variations in inflammatory genes are associated with periodontitis. Immunity and Ageing. 2013; 10(39): 1-8. doi: 10.1186/1742-4933-10-39

2. Mulot C, Stucker I, Clavel J, Beune P, Loriot MA. Collection of human genetic DNA from buccal cells for genetic studies: comparison between cytobrush, mouthwash, and treated card. J Biotechnol. 2005; 2005(3): 291-296. doi: 10.1155/JBB.2005.291

3. Bartova J, Linhartova PB, Podzimek S, Janatova T, Svobodova K, Fassmann A, Duskova J, Belacek J, Holla LI. The Effect of IL-4 Gene Polymorphisms on Cytokine Production in Patients with Chronic Periodontitis and in Healthy Controls. Mediators Inflamm. 2014; 2014: 185757. doi: 10.1155/2014/185757 
4. Newman MG, Takei HH, Klokkevold PR. Carranza's Clinical Periodontology; 2015. 473.

5. Heidari $Z$. The association between Proinflammatory gene polymorphsms and level of gingival tissue degradation in chronic periodontitis. Gene Cell Tissue. 2014; 1: 2.

6. Psifidi A, Dovas Cl, Bramis G, Lazou T, Russel CL, Arsenos G, Banos G. Comparison of eleven methods for genomic DNA extraction suitable for large-scale whole-genome genotyping and long-term DNA banking using blood samples. PLoS One. 2015; 10(1): e0115960. doi: 10.1371/journal.pone.0115960

7. Finkel MA, Giardino AP. Medical Evaluation of Child Sexual Abuse. New Delhi: Sage Publication; 2002. 139.

8. Tanjaya J, Auerkari El. IL-1 $\beta$ genetic polymorphism in menopause women as periodontal disease risk factor. Journal of Dentistry Indonesia. 2011; 18(1): 1-5. doi: 10.14693/jdi.v18i1.52
9. Kwok P, Chen X. Detection of single nucleotide polymorphisms. Curr Issues Mol Biol. 2003; 5(2): 43-60.

10. Robati $M$, Ranjbari $A$, Boroujerdnia $M$, Chinipardaz Z. Detection of IL-4, IL-6, and IL-12 serum levels in generalized aggresive periodontitis. Iran J Immunol. 2011; 8(3): 170-175.

11. Atanasovska-Stojanovic A, Trajkov D, Nares S, Angelov N, Spiroski M. IL-4 gene polymorphisms and their relation to periodontal disease in Macedonian population. Hum Immunol. 2011; 72(5): 446-450. doi: 10.1016/j.humimm.2011.02.005. 